\title{
Guidance of Self-protection efforts during the covid-19 pandemic, through community empowerment activities in Kasugengan Kidul Village, Depok Cirebon
}

\author{
lin Indawati, Aan Kunaedi a), Anis Selawati, and Elva Angela \\ School of Pharmacy Muhammadiyah Cirebon, Indonesia \\ a)Corresponding author: ankunaedi@gmail.com
}

\begin{abstract}
The impact of the Covid-19 pandemic in Indonesia continues increasing significantly, even positive cases reached up to $235,173,857$ people. The existence of Student Work Study (KKM) activities is expected to make a positive contribution during the Covid-19 pandemic that hit Indonesia. In connection with the condition of the spread of Covid-19 which is still increasing, KKM implementation activities in Kesugengan Kidul village, Depok Subdistrict, Cirebon Regency must certainly be creative in order to stay safe and the purpose of activities is achieved. Starting from student fielding and data collection of partnership problems by applying health protocols properly. The method of carrying out activities is carried out with various efforts, including by providing education through leaflets, brochures, sticking brochures on the walls of elementary schools, by limiting the implementation of learning activities, provide education and examples of vitamins both tablets and derived from fruit in the form of nutritious foods that the body needs during the Covid-19 pandemic, even educating through door to door method to local citizen. Expectation of understanding and insight of citizens in the place of KKM partnerships are increasing about the prevention of Covid-19. The results and benefits of KKM activities towards partnerships include increasing public awareness of the prevention of Covid-19, one of which understands the importance of using masks, especially 2-layer masks. The community is more cooperative towards the efforts and programs of village officials to prevent the increase in the spread of the Covid-19 virus, increased citizen insight in partnership on vitamins needed and useful to increase endurance to fight covid-19 and discipline to implement health protocols in an effort to prevent and suppress the spread of Covid-19 in the partnership area of Kesugengan Kidul Village, Depok Subdistrict, Cirebon Regency.
\end{abstract}

Keywords: Covid-19 prevention education, Kasugengan Kidul Village, Kuliah Kerja Mahasiswa.

\section{INTRODUCTION}

Covid-19 that hit the whole world, even (worldodometer.com, 2021) update dated October 2, 2021 reported the number of coronavirus cases reached $235,173,857$ people, with the number of deaths $4,807,892$ people and cures $211,920,827$ people. The increasing surge in cases, including Indonesia, made the government have to take a policy of Imposing Restrictions on Community Activities (PPKM) as of July 3, 2021 through a press release of the State Palace by President Joko Widodo due to the impact of a very high case spike with a $381 \%$ increase posted by (Ministry of Foreign Affairs, 2021).Various government efforts in handling Covid-19 so far aim to contain the rate of increase in cases that have the worst impact to death. One of the prevention efforts urged by the government through a government spokesman for Covid-19 dr. Achmad Yurianto said that discipline to stay home, keep a distance, and wear a mask when leaving the house, wash hands properly and properly and consume nutritious food and vitamins is the best way to prevent the increasing spread of Covid-19. This appeal is also in line with the appeal from Unicef Indonesia contained in its website (UNICEF INDONESIA, 2021). Support the government's efforts in improving the discipline of Covid-19 prevention to the community, through student study field (KKM) one of them by providing education to the community related to Covid-19. This devotional activity was carried out educationally themed "Optimization of selfprotection efforts against the Covid-19 virus, and increased immunity during the Covid-19 pandemic.

KKM activities carried out by students as a generation of change drivers, many provide positive value to the community. (Wedyawati \& Lisa, 2019) and (Yuslistyari et al., 2020) 
through KKM activities can have a positive impact on the change of targets of devotional activities. This devotional activity also hopes to provide benefits in the area of KKM activities, namely the community of Kesugengan Kidul Village, Depok Subdistrict, Cirebon Regency.

\section{METHOD}

The implementation method is carried out with 3 stages: The first stage, socialization on August 17, 2021 with Mr. Nuryanto as the Head of Kasugengan Kidul Village, to record problems / obstacles in the partnership. Based on the first stage formulated several problems, including: Lack of sufferingand understanding of citizens on the prevention of Covid-19, lack of understanding of the use of vitamins to increase immunity in the Covid-19 pandemic, including education on the use of masks that are good and correct. The second stage of the implementation of activities that are divided into several days, including on August 27, 2021 in the implementationof educational extension activities accompanied by distributing posters on the board informasi Kesugengan Kidul Village on how to use a good and correct mask. On August 30, 2021, education and counseling was carried out accompanied by the distribution of vitamin samples (vitamin C) (Khairita, 2021) to prevent Covid-19 directly to the mothers of the surrounding residents and put a poster "how to use a 2-layer mask and keep your distance" in the school wall magazine. On September 4, 2021, education on vitamins was conducted by distributing examples of vitamin foods (fruit pudding) door to door to neighbors (mothers andchildren). The method through counseling is effective enough to provide education and understanding to the citizens (Rahman \& Patilaiya, 2018) as a form of student work lectures in Kasugengan Kidul Village, Depok District, Cirebon Regency when the conditions impose restrictions on community activities.

\section{RESULTS}

The results of devotional activities through counseling are obtained to increase knowledge and understanding of the community related to the prevention of Covid-19. This has the impact of increasing public awareness and a more concerned attitude to discipline to efforts to prevent covid 19 under any circumstances (Ritonga \& Siregar, 2020). As well as being more cooperative with village officials in an effort to prevent the spread of Covid-19. This is similar to the benefits of devotional activities carried out (Buheli et al., 2020) and (Hafizhdillah et al., 2021) where counseling can increase public knowledge in preventing Covid-19, by way of disciplined implementation of health protocols and consuming vitamins both tablets and derived from fruits.

\section{DISCUSSION}

In connection with the condition of PPKM the implementation of devotional activities is modified with door to door to get maximum results. In figure 1. and figure 2 is shown educational extension activities and distributes brochures "Vitaminneeds and foods with balanced nutrition"where the parameters of balanced nutrition must contain water, protein, carbohydrates, fats, fiber, calcium, Fe and and vitamin C (Permatasari et al., 2020). Equipped with an example of vitamin foods inthe form of pudding that contains vitamins from fruits, especially for children. Fruit pudding is one of the options to meet the needs of vitamins to boost the immune system because the fruit is a source of vitamin $C$ that is able to boost our immunity (Yahya, 2017). In figure 3. Shown socialization activities through attaching the brochure "Cara increases endurance in the time of the covid-19 pandemic" in majalah dinding Kasugengan Kidul Village. It aims to increase knowledge of how to increase the body'sresistance at the time of apandemic. In figure 4. Distributed brochures about the importance of wearing two-layer masks during the pandemic to the Kasungengan Kidul Village device. This activity aims to increase public awareness of using masks properly and correctly in an effort to break the chain of transmission of Covid-19 (Amalia et al., 2021). In figure 5. Shown education to wear a two-layer mask through the distribution of two-layer masks to children in SDN 2 Kasugengan Kidul, in hopes of creating habits to younger siblings in basic schools to better understand and understand the dangers of the Covid-19 virus and how to be prevented from the Covid-19virus. In figure 6 , there is a 
brochure-stamping activity in the school wall magazine SDN 2 Kasugengan Kidul as an effort to prevent Covid 19 in the school area to increase knowledge and change the behavior of the community, especially students and students and Ibu Bapak teachers including the school cafeteria area shown in figure 7 , in order to still be able toconducting discipline to prevent the transmission of covid 19 during learning activities (Ritonga \& Siregar, 2020). Overall, this devotion received a strong appreciation from the residents of Kasugengan Kidul Village, residents look enthusiastic especially when receiving vitamin tablets given and are willing to take them at home (Fitria et al., 2021).

\section{CONCLUSIONS AND RECOMMENDATIONS}

Community service activities through KKM aim to increase public awareness of kasugengan kidul village towards self-protection in the face of the covid-19 pandemic. Done through education and counseling accompanied by the installation of posters and the distribution of brochures on how to wear masks properly and correctly equipped with the distribution of vitamin samples in the form of vitamin $\mathrm{C}$ tablets and fruit pudding. So it is expected that the people of Kasugengan Kidul Village better understand and understand the dangers of the Covid19 virus and how to avoid the virus (Amalia et al., 2021). Efforts to fulfill vitamins to deal with covid-19 can be done by consuming fruit pudding foods (Rantika et al., 2020).

\section{ACKNOWLEDGMENTS}

Thanks to Mr. Nuryanto, as the Village Head and village apparatus. Mother and Father of SDN 2 teacher Kasugengan Kidul and the community of housing residents Graha Kencana Kasugengan Kidul Village, Depok District, Cirebon Regency.

\section{REFERENCES}

Amalia, A., Dewi, C. K., Aribah, N., Firnandi, N. P., Yuniar, S. T., \& Surahman, A. (2021). PENYULUHAN DAN PEMAHAMAN PENTINGNYA MANFAAT 3M (MEMAKAI MASKER, MENCUCI TANGAN, DAN MENJAGA JARAK) UNTUK MEMUTUS RANTAI PENULARAN COVID-19 DI MASYARAKAT. Jurnal Pengabdian Kepada Masyarakat (PKM): Kreasi Mahasiswa Manajemen, 1(2), 91-98.

Buheli, K. L., Usman, L., Ischak, W. I., \& Tomayahu, M. (2020). Peningkatan Daya Tahan Tubuh Melalui Hidup Bersih Sehat, Konsumsi Vitamin C Serta Madu Dalam Pencegahan COVID-19 Di Desa Yosonegoro. Prosiding Seminar Nasional Unimus, 3(0).

Hafizhdillah, A. R., Purwaningrum, R., Kheru, A., Eksa, D. R., Mustofa, F. L., \& Rafie, R. (2021). Penyuluhan Pencegahan Penularan Corona Virus dengan Mematuhi Protokol Kesehatan di Puskesmas Rawat Inap Kota Karang Bandar Lampung. JURNAL KREATIVITAS PENGABDIAN KEPADA MASYARAKAT (PKM), 4(1), 200-206. https://doi.org/10.33024/jkpm.v4i1.3674

Kementerian Luar Negeri RI. (2021). PEMBERLAKUAN PEMBATASAN KEGIATAN MASYARAKAT (PPKM) DARURAT 3-20 JULI 2021. Kemlu.Go.Id. $\mathrm{https}: / / \mathrm{kemlu} . \mathrm{go} . \mathrm{id} / \mathrm{madrid} / \mathrm{id} / \mathrm{news} / 14339 / \quad$ pemberlakuan-pembatasan-kegiatanmasyarakat-ppkm-darurat-3-20-juli-2021

Khairita, N. (2021). Education and Distribution of Vitamin C to Village Communities The Spirit of Service So that People Can Maintain Immunity during the Covid-19 Pandemic. 759764.

Rantika, Indani, \& Hamid, Y. H. (2020). DAYA TERIMA KONSUMEN TERHADAP PUDING DENGAN PENAMBAHAN BUAH RIMBANG (Solanum Torvum SW.). Jurnal IImiah Mahasiswa Pendidikan Kesejahteraan Keluarga, 5(1), 23-31.

Ritonga, N., \& Siregar, N. (2020). PENYULUHAN TENTANG PENCEGAHAN PENULARAN COVID 19 DENGAN MEDIA BROSUR DAN POSTER DI AREA MESJID DESA SIHOPUR KECAMATAN ANGKOLA SELATAN TAPANULI SELATAN TAHUN 2020. Jurnal Pengabdian Masyarakat Aufa (JPMA), 2(2), 47-51. 
UNICEF INDONESIA. (2021). Novel Coronavirus (COVID-19): Hal-hal yang perlu Anda ketahui UNICEF Indonesia.

https://www.unicef.org/indonesia/id/ Https://Www.Unicef.Org/Indonesia/ld/. coronavirus?gclid=CjwKCAjwqeWKBhBFEiwABo coronavirus/tanya-jawab-seputarXBv76jMrKlgdEdc0ipoBFH0A56dwVjGW7v1aixPsOZIXsoJBil49MyBoClfgQAvD_BwE\#b agaimanacoronavirusmenyebar

Wedyawati, N., \& Lisa, Y. (2019). Peningkatan Rasa Kesadaran Bahaya Minuman Keras dengan Pendekatan Eksperimen Melalui PPL-KKM di SDN 11 Bora Desa Kecamatan Sayan Kabupaten Melawi. Jurnal Pengabdian Masyarakat Khatulistiwa, 2(1), 17-25. https://doi.org/10.31932/JPMK.V2I1.425

worldodometer.com. (2021). COVID https://www.worldometers.info/coronavirus/

Live Update: - Worldometer.

Yuslistyari, E. I., Ramayanti, G., Umama, H. A., Sari, M. M., Surya, A. A., \& Sakti, R. (2020). Knowledge Sharing Mahasiswa KKM Melalui Pemanfaatan Limbah Kertas Menjadi Kerajinan Tangan. Journal of Dedicators Community, 3(3), 11-21. https://doi.org/10.34001/jdc.v3i3.1035 


\section{APPENDIX}

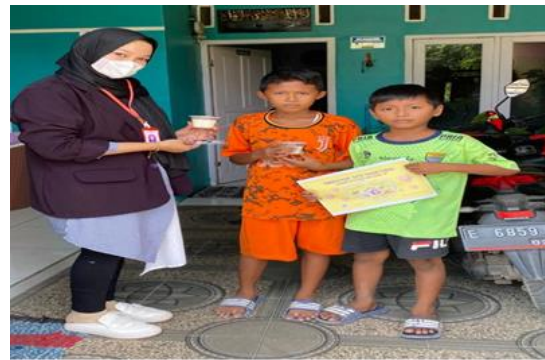

Figure 1. Citizen Education and memprovide examples of nutritious foods with vitamin fruits and brochures in children

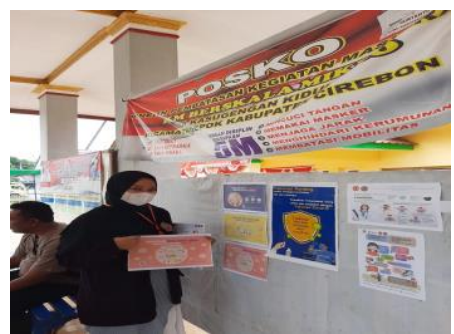

Figure 3. Extension of Partnership Citizen Education through brochure "howto increase endurance during the covid-19 pandemic" around the partnership area and Kasungan Kidul Village Notice Board

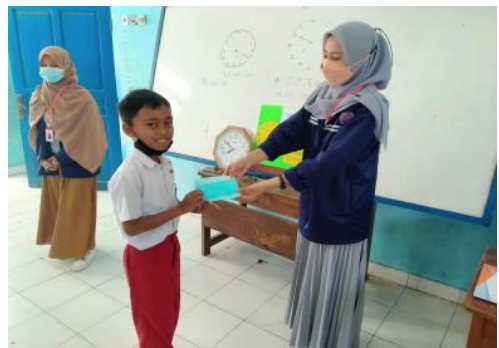

Figure 5. Counseling and Education uses twolayer masks to children in SDN 2 Kasugengan kidul.

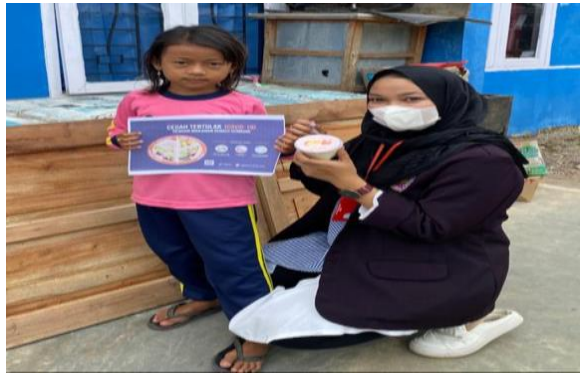

Figure 2. Education of Citizens and memprovide examples of nutritious foods with vitamin fruits and brochures to children in Kasugengan Kidul Village

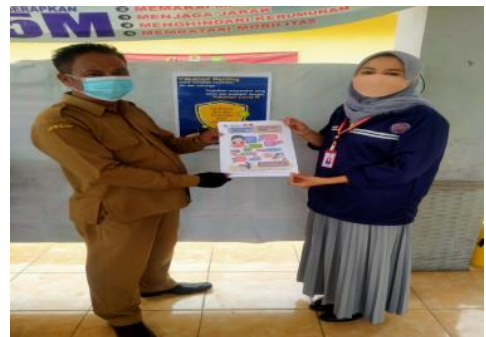

Figure 4. Education extension as well as distributing brochures "theimportance of wearing two-layer masks during the pandemic" to the Kasungengan Kidul Village device

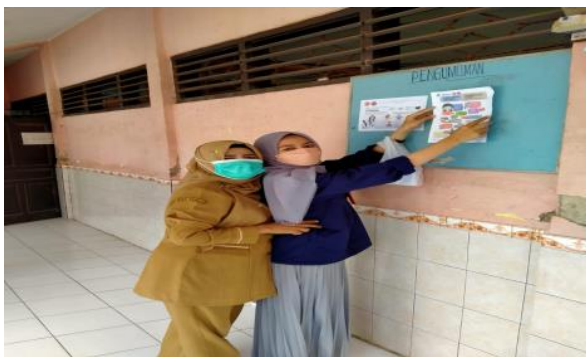

Figure 6. Counseling and education through brochures in the school wall magazine SDN 2 Kasugengan Kidul.

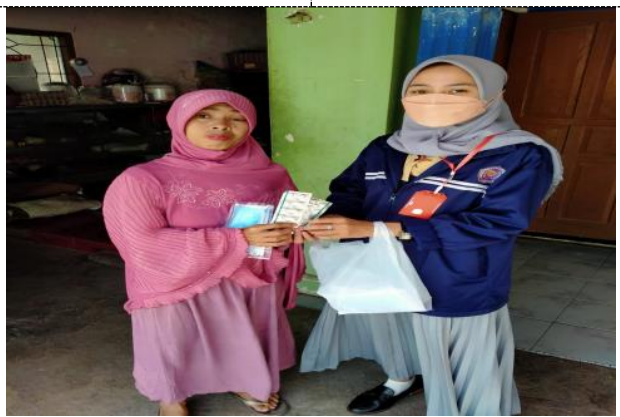

Figure 7. Counseling Residents door to door once ishare two layers of masks and vitamin tablets to the people of Kasugengan Kidu Villagel. 